\title{
GEOLOGY OF THE CHUGACH-PRINCE WILLIAM TERRANE IN NORTHERN PRINCE WILLIAM SOUND, ALASKA
}

JOHN I. GARVER, Union College

CAMERON DAVIDSON, Carleton College

\section{INTRODUCTION}

This six-student project focused on the geology of the Chugach and Prince William terranes in northern Prince William Sound, Alaska. The Chugach-Prince William (CPW) composite terrane is a MesozoicTertiary accretionary complex that is well exposed for $\sim 2200 \mathrm{~km}$ in southern Alaska and is inferred to be one of the thickest accretionary complexes in the world (Plafker et al., 1994; Cowan, 2003). The CPW terrane is bounded to the north by the Border Ranges fault, which shows abundant evidence of Tertiary dextral strike slip faulting, and inboard terranes of the Wrangellia composite terrane (Peninsular, Wrangellia, Alexander) (Pavlis, 1982; Cowan, 2003; Roeske et al., 2003). Throughout much of the $2200 \mathrm{~km}$ long belt of the CPW terrane it is bounded by the offshore modern accretionary complex of the Alaskan margin, but east of Prince William Sound the Yakutat block is colliding into the CPW and this young collision has significantly affected uplift and exhumation of inboard rocks.

Most of the Chugach and Prince William terranes are comprised of imbricated trench-fill turbidites deposited over a relatively short interval of time (Campanian to Paleocene - c. 75-52 Ma; Garver and Davidson, 2015; Davidson and Garver, 2017) and by some estimates the volume of sediment is between 1-2 million km3 (i.e. Decker, 1980; Sample and Reid, 2003). In Prince William Sound, the turbidites of the Chugach and Prince William terranes are known as the Valdez and Orca groups, respectively, and are separated by the Contact fault (Fig. 1). In northern Prince William Sound the Contact fault (aka Jack Bay fault) is dominated by strike-slip motion (Bol and
Roeske, 1993; Haeussler and Nelson, 1993), and in the west, it is less well defined, but shows evidence for dip-slip motion (Bol and Gibbons, 1992). The turbidites are interbedded with mafic igneous rocks (pillow basalts and locally full ophiolitic suites of Resurrection Bay, Knight Island, and Glacier Island). In sharp contrast to the published literature, we suggested that the ophiolites were actually formed in a supra-subduction zone setting that coincided with oblique rifting of the Orca basin (Davidson and Garver, 2017). A critical part of our argument is that the "ophiolite" rocks are interbedded with the Orca turbidites, and their geochemistry suggests that depleted mantle melts are modified by assimilation of the sediments (Noseworthy, this volume).

Very soon after imbrication and accretion to the continental margin, rocks of the CPW were intruded by near-trench plutons of the Sanak-Baranof belt that has a distinct age progression starting in the west (63 $\mathrm{Ma}$ in the Sanak-Shumagin areas far to the west) and getting progressively younger to the east (53-47 Ma on Baranof Island; Bradley et al., 2000; Haeussler et al., 2003; Kusky et al., 2003; Farris et al., 2006; Wackett et al., in revision). In western Prince William Sound, these rocks were also intruded by the 37-41 Ma Eshamy Suite of plutons (Johnson, 2012; Garcia, this volume).

Paleomagnetic and geologic data indicate that the CPW has experienced significant coast-parallel transport in the Tertiary (see Garver and Davidson, 2015). The CPW has apparent equivalents to the south, and this geologic match suggests that in the Eocene, the southern part of the Chugach-Prince William terrane was contiguous with the nearly 


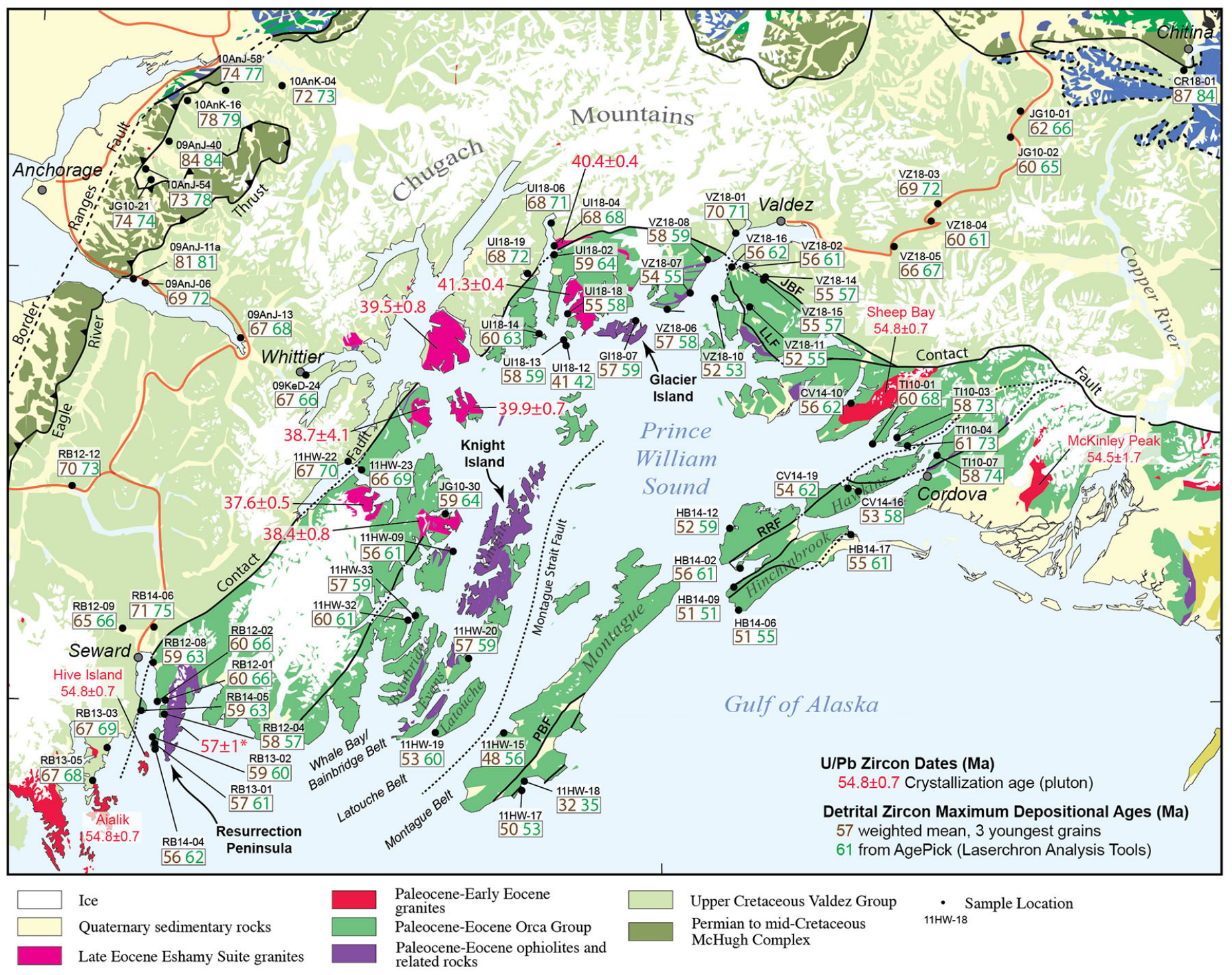

Figure 1. Geologic map of southern Alaska (modified from Bradley et al., 2003). Sample locations with maximum depositional ages (Ma) and pluton ages (Ma) are shown. The focus for the 2018 field season was northern Prince William sound near Valdez and along the Richardson highway.

identical Leech River Schist exposed on the southern part of Vancouver Island (Cowan, 1982; 2003). The geological implication of this hypothesis is profound yet elegant in the context of the Cordilleran tectonic puzzle: the CPW is the Late Cretaceous to Early Tertiary accretionary complex to the Coast Mountains Batholith Complex that intrudes the Wrangellia composite terrane and North America. Thus, the $\mathrm{CPW}$ is inferred to have accumulated in a flanking trench to the west and then soon thereafter these rocks were accreted to the margin. This geologic match is elegant because it suggests that the CPW accumulated outboard the Coast Mountains Batholith Complex (Gehrels et al., 2009) and that the CPW essentially is the erosional remnants of that orogenic belt.

\section{RESEARCH}

We had a terrific group of six students from four different colleges and universities (Fig. 2). Below we describe the four main research questions we studied and where the students made their contributions.

\section{1) Provenance and maximum depositional ages of sandstones and conglomerates of the Valdez and Orca Groups in Northern Prince William Sound.}

One of the primary goals of this research was to work out the relationship between the turbidites of the Valdez and Orca Groups in Prince William sound. Previous preliminary work along the Richardson highway (Fig. 1) suggests that the Valdez Group might 


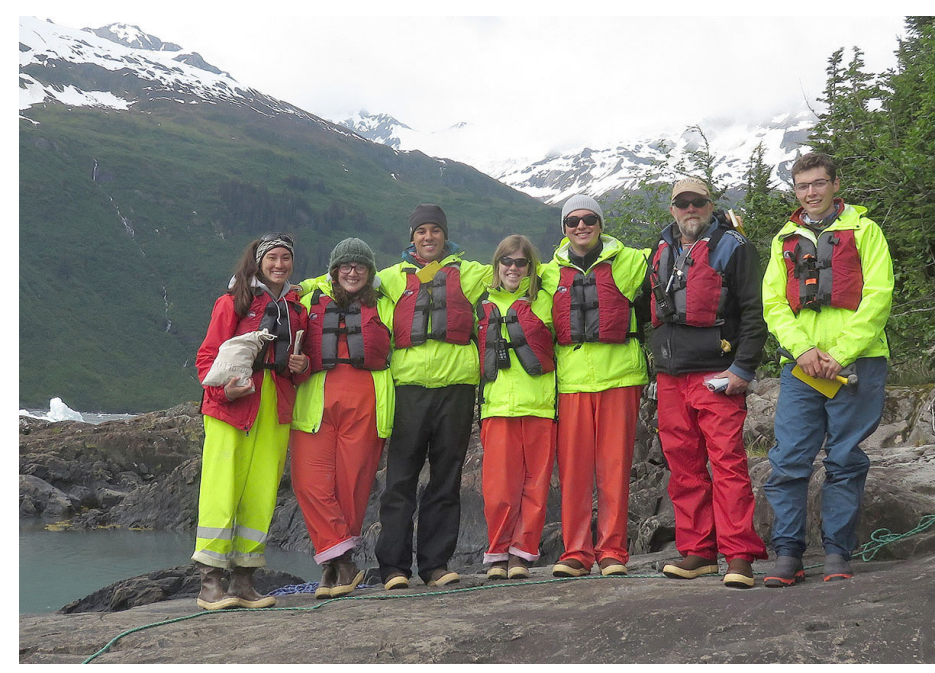

Figure 2. The 2018 Keck Alaska team collecting a detrital zircon sample in Unakwik Inlet.

be as young as $60 \mathrm{Ma}$, and the age and provenance of the Orca and Valdez group using detrital zircons in this area had not been studied until now.

Will Fisher (Union College) focused on the age of detrital zircon from the Orca Group and was able show that there are four distinct zircon facies defined by maximum deposition age and grain-age distributions. He also used shale geochemistry collected from the Orca and Valdez Groups to show that there is very little difference in the trace element composition suggesting that the source area for shales in these rocks is indistinguishable. An important implication of Will's work is that the differences in provenance implied by the different zircon facies is not reflected in shale geochemistry suggesting that at least for this area and time period, shale geochemistry is too coarse a tool to help work out the provenance of these rocks.

Nick Gross-Almonte (Carleton College) studied the age of detrital zircon from the Valdez Group and was able to confirm the existence of young packages of turbidites (60-62 Ma) within the older (>66Ma) Valdez Group rocks along the Richardson highway. Based on maximum deposition age and grain-age distributions, he defines four different zircon facies including a Paleocene facies, and three distinct Cretaceous facies. This work is important because it shows that the Valdez Group is younger than previously described and that these younger rocks were either folded into the older Valdez Group turbidites, or were emplaced as structural slices during accretion.
Mollie Pope (Union College) focused on the origin and age of pebble and6/10/19 boulder conglomerates found in the Orca Group. She shows that in more than one location, the age of well-rounded sandstone clasts are the same age as the matrix (within error). Furthermore, some of these clasts have hydrothermal veins with greenschist facies minerals including epidote suggesting that these rocks were deposited, buried, and exhumed in a short period of time.eeees

\section{2) Significance of the Contact Fault in Prince}

William Sound. The contact between the Valdez and Orca Groups in Prince William sound has traditionally been mapped as the Contact fault and is the proposed terrane boundary between the Chugach and Prince William terranes (e.g. Plafker et al., 1994). A number of workers have questioned the importance of this structure (Bol and Gibbons, 1992; Bol and Roeske, 1993), or whether a fault even exits (e.g. Dumoulin, 1988).

Alysala Malik (Carleton College) studied detrital zircon ages from either side of the Contact fault system across Prince William Sound to look for discontinuities in depositional age and grain age distributions in the Orca and Valdez groups as would be predicted if the fault is a terrane bounding structure. She was able to show that the Jack Bay fault in Valdez Arm does not separate rocks of different age or significantly different zircon populations; but the Eaglik fault in Unakwik inlet does. She also shows that there is a panel of turbidites that are significantly younger ( $\sim 52 \mathrm{Ma})$ than rocks immediately north or south, and appear to correlate with rocks of similar age and stratigraphic character farther south on Hinchinbrook island.

\section{3) Petrology and age of the Cedar Bay and Miners} Bay plutons. Previous work on the Cedar Bay and Miners Bay plutons suggest that these plutons belong to the 37-40 Ma Eshamy Suite which intrude the Valdez and Orca Groups in western Prince William Sound (Johnson, 2012). However, the geochronology from these rocks was ambiguous (Nelson et al., 1999).

\section{Victor Garcia (University of Texas, Austin)} collected and an analyzed 14 samples from the Miners Bay and Cedar Bay plutons for whole rock geochemistry and five samples for U-Pb zircon dating 
and Hf isotope geochemistry. He shows that these plutons yield ages between 40.4 - 41.5 Ma, and do indeed correlate in age with the Eshamy suite. The Hf isotope ratios are similar as well and suggest these rocks were derived from a rather primitive source region $(\varepsilon \mathrm{Hf}=+4$ to +10$)$.

\section{4) Petrology of the Glacier Island ophiolite}

complex. Mafic volcanic rocks, mostly pillow basalt, are an important part of the Orca Group and are found interbedded with turbidites throughout Prince William Sound. Locally, these rocks dominate and in places appear to form what have been described as ophiolites complete with sheeted dike complexes and in some cases ultramafic rocks (Nelson and Nelson, 1992).

Caitlin Noseworthy (St Norbert College) collected 14 samples from the Glacier Island ophiolite complex and three samples from mafic volcanic rocks interbedded with turbidites for whole rock geochemistry. She also determined the maximum depositional age of a sandstone bed cut by a dike on Glacier Island. She shows that the Glacier Island ophiolite came from a depleted mantle (NMORB) source and is similar in age and geochemistry to the Resurrection and Knight Island ophiolites in western Prince William Sound.

\section{ACKNOWLEDGEMENTS}

This research was funded by a collaborative grant NSF EAR 1728013 (to J. Garver, Union College) and EAR 1727991 (to C. Davidson, Carleton College) and by the NSF Grant 1659322 to the Keck Geology Consortium (Macalester College). We are indebted to the extraordinary efforts by D. Giesler, M. Pecha and G. Gehrels at the Arizona LaserChron Center, which is an NSF multi-user facility at the University of Arizona. Hamilton Analytical Laboratory provided XRF and ICP-MS analyses for major and trace element data. We appreciate the visit, help in the field, and mentoring efforts of Prof. Tim Flood (St. Norbert College) and the mentoring efforts of Prof. Daniel Stockli (UT-Austin).

\section{REFERENCES}

Bol, A.J. and Gibbons, H., 1992, Tectonic implications of out-of-sequence faults in an accretionary prism, Prince William Sound, Alaska: Tectonics, v.1, p. 1288-1300.

Bol, A.J., and Roeske, S.M., 1993, Strike-slip faulting and block rotation along the contact fault system, eastern Prince William Sound, Alaska. Tectonics 12, 49-62.

Bradley, D. C.; Parrish, R.; Clendenen, W.; Lux, D.; Layer, P.; Heizler, M.; and Donley, D. T., 2000, New geochronological evidence for the timing of early Tertiary ridge subduction in southern Alaska: US Geological Survey Professional Paper, 1615:5-21.

Bradley, D.C., Kusly, T.M., Haeussler, P.J., Goldfarb, R.J., Miller, M.L., Dumoulinf, J.A., Nelson, S.W. \& Karl, S. M., 2003, Geologic signature of early Tertiary rifge subduction in Alaska: Geology of transpressional orogen developed during ridgetrench interaction along the North Pacific margin: Geological Society of America Special Paper, v. 371, p. 19-49.

Cowan, D.S., 1982, Geological evidence for post-40 m.y. B.P. large-scale northwestward displacement of part of southeastern Alaska, Geology, v. 10 p. 309-313.

Cowan, D.S., 2003, Revisiting the Baranof-Leech River hypothesis for early Tertiary coastwise transport of the Chugach-Prince William terrane. Earth and Planetary Science Letters, v. 213, 463475.

Decker, J.E., Jr., 1980. Geology of a Cretaceous subduction complex, western Chichagof Island, Southeastern Alaska. PhD. Thesis, Stanford University, $135 \mathrm{p}$.

Davidson, C. and Garver, J.I., 2017, Age and origin of the Resurrection Ophiolite and associated turbidites of the Chugach-Prince William terrane, Kenai Peninsula, Alaska. Journal of Geology, v. 125, p. 681-700. doi:10.1086/693926. 
Farris, D.W., Haeussler, P., Friedman, R., Paterson, S.R., Saltus, R.W. \& Ayuso, R. 2006, Emplacement of the Kodiak Batholith and slab-window migration, Geological Society of America Bulletin, vol. 118, no. 11-12, pp. 13601376.

Garver, J. I., and Davidson, C., 2015, Southwestern Laurentian zircons in Upper Cretaceous flysch of the Chugach-Prince William terrane in Alaska: American Journal of Science, 315:537-556.

Gehrels, G.E., Rusmore, M., Woodsworth, G., Crawford, M., Andronicos, C., Hollister, L., Patchett, J., Ducea, M., Butler, R., Klepeis, K, Davidson, C., Mahoney, B., Friedman, R., Haggard, J, Crawford, W., Pearson, D., Girardi, J., 2009, U-Th-Pb geochronology of the Coast Mountains Batholith in north-coastal British Columbia: constraints on age, petrogenesis, and tectonic evolution. Bulletin of the Geological Society of America, v. 121, p. 1341-1361.

Haeussler, P.J., and Nelson, S.W., 1993, Structural evolution of the Chugach-Prince William terrane at the hinge of the orocline in Prince William Sound and implications for ore deposits, in Dusel-Bacon, Cynthia, and Till, A.B., eds., Geologic Studies in Alaska by the U.S. Geological Survey, 1992: U.S. Geological Survey Bulletin 2068, p. 130-142.

Haeussler, P.J., Bradley, D.C., Wells, R.E. \& Miller, M.L. 2003, Life and death of the Resurrection Plate; evidence for its existence and subduction in the northeastern Pacific in Paleocene-Eocene time, Geological Society of America Bulletin, vol. 115 , no. 7 , pp. 867-880.

Johnson, E., 2012, Origin of Late Eocene granitiods in western Prince William Sound, Alaska; Proceedings from the 25th Keck Geology Consortium Undergraduate Research Symposium, Amherst MA, p. 33-39.

Kusky, T.M., Bradley, D.C., Donely, D.T., Rowley, D. \& Haeussler, P.J. 2003, Controls on intrusion of near-trench magmas of the Sanak-Baranof Belt, Alaska, during Paleogene ridge subduction, and consequences for forearc evolution; Geology of a transpressional orogen developed during ridgetrench interaction along the North Pacific margin, Special Paper - Geological Society of America, vol. 371, pp. 269-292.

Nelson, S. W.; and Nelson, M. S., 1993. Geochemistry of ophiolitic rocks from Knight Island, Prince William Sound, Alaska: U. S. Geological Survey Bulletin, p. 130-142.

Nelson, S. W., Miller, M.L., Haeussler, P.J., Snee, L. W., Phillips, P.J., and Huber, C., 1999, Preliminary geologic map of the Chugach National Forest Special Study Area, Alaska: U.S. Geological Survey Open-File Report 99-362, scale I :63,000.

Pavlis, T.L., 1982, Origin and age of the Border Ranges Fault of southern Alaska and its bearing on the late Mesozoic Tectonic Evolution of Alaska: Tectonics, v. 1, n. 4, p. 343-368.

Plafker, G., Moore, J.C. \& Winkler, G.R. 1994, Geology of the Southern Alaska margin in The geology of Alaska, eds. G. Plafker \& H.C. Berg, Geological Society of America, Boulder, CO, United States (USA), United States (USA).

Roeske, S.M., Snee, L.W. \& Pavlis, T.L. 2003, Dextral-slip reactivation of an arc-forearc boundary during Late Cretaceous-early Eocene oblique convergence in the northern Cordillera; Geology of a transpressional orogen developed during ridge-trench interaction along the North Pacific margin, Special Paper - Geological Society of America, vol. 371, pp. 141-169.

Sample, J.C. \& Reid, M.R. 2003, Large-scale, latest Cretaceous uplift along the Northeast Pacific Rim; evidence from sediment volume, sandstone petrography, and $\mathrm{Nd}$ isotope signatures of the Kodiak Formation, Kodiak Islands, Alaska; Geology of a transpressional orogen developed during ridge-trench interaction along the North Pacific margin, Special Paper - Geological Society of America, vol. 371, pp. 51-70. 